\title{
The effect of increasing seatwork time on English achievement of high school freshmen
}

\author{
Mojtaba Maghsoudi, Abolfazl Khodamoradi
}

Farhangian University, Shahid Bahonar branch, Arak

Email address:

maghsudim@yahoo.com (M. Maghsoudi)

\section{To cite this article:}

Mojtaba Maghsoudi, Abolfazl Khodamoradi. The Effect of Increasing Seatwork Time on English Achievement of High School Freshmen. International Journal of Language and Linguistics. Special Issue: Language Teaching and Learning Key Principles (LTLKP).

Vol. 1, No. 4-1, 2013, pp. 53-59. doi: 10.11648/j.ij1l.s.20130101.19

\begin{abstract}
This study aimed at investigating the effect of increasing seatwork time on the achievement of high school freshmen in English classes. In a quasi-experimental design two intact classes were randomly selected from the population of ten classes in a high school. Both classes were given the same amount of seatwork time (1/3 ${ }^{\text {rd }}$ of allocated time) in the first semester before pre-test. For the second semester, the experimental group had more time for seatwork activities $\left(2 / 3^{\text {rd }}\right.$ of allocated time) while the seatwork time for control class remained unchanged. At the end of the semester the participants' achievement was assessed in a post-test. The results of ANCOVA showed that the participants' gained scores in post-test between the groups were not significantly different, $f(1,47)=2.85, p<0.05$. It indicated that increasing seatwork time doesn't have any significant effect on the learners' achievement in English classes.
\end{abstract}

Keywords: Seatwork Time, English Achievement, and Allocated Time

\section{Introduction}

For many educationalists, ideal education means interaction between learners and instructional materials in a context in which teachers play the role of facilitators. Such a role for teachers in pedagogy is advocated by those educational theorists who repudiate the teacher to act as an authority in the classroom transmitting knowledge to students who are considered as receptacles. These theorists who were initially inspired by John Dewey's (1916) inquiry-based philosophy of education view learning more complex than unidirectional transmission of information from teachers to learners. These innovative views propose three kinds of interaction in any learning situation: learnercontent interaction, learner-teacher interaction, and learnerlearner interaction (Moore \& Kearsley, 1996). Soo and Bonk (1998) added a fourth type on interaction, the learnerself interaction which highlighted the importance of mental engagement with learning materials. This forth type of interaction is taken as a subtype of learner-content interaction by some theorists like Tuovinen (2000).

Such an ideal democratic student-centered view towards education advocated by theorists is lagging behind in most educational settings. When it comes to be actualized in classroom, teachers follow the traditional transmission model although they support the theoretical bases of the innovative interactive models. In fact in struggle between the theoretical knowledge on the one hand, and the teachers' conceptualization of their situation on the other hand, the latter is far more influential than the former (Pajares; cited in Williams \& Burden, 1997). This dominance which amounts to the teachers' appeal to transmission model is simply apparent in their classroom arrangement, in their teaching approach, and most noticeably in their time allocation.

The time allocated to learners and teachers can reveal the quality of instruction in terms of teacher-centeredness and learner-centeredness. In every classroom, time is divided proportionally between teachers for whole-class instruction and learners for seatwork activities. The ratio of "wholeclass instruction time" to "seatwork time" gives us a time proportional scale as an indicator of the degree of learners' autonomy. In classes run in traditional approach, this ratio shows that the time is allocated unevenly with more amount of time for teachers' lectured-based instruction and less for learners' independent learning. Teachers' tendency to keep the whole class instruction as their dominant approach is not justifiable while the bulk of research 
findings view this approach in disrepute. The contradiction between what theorists recommend and what teachers perform in terms of time allocation needs to be resolved in a research study. The results of this study can provide both parties with some criteria to evaluate their conceptualizations of the truth and reality of learning process. Specifically, if time allocation changes as theorists urge teachers to do and leads to better achievement, this can furnish teachers with a professional instrument to reflect on their practice and replace their traditional role of sage on the stage with more innovative role of guide on the side.

\section{Review of Related Literature}

It is for four decades that the concept of instructional time has been considered as a variable which contributes to the learners' achievement. Researchers in domain of educational time factors often refer to Carroll's influential article in 1963 as the starting point for a new brand of studies which gave the time factor a pivotal role among learning factors. In his brief but ambitious article "A Model of School Learning," John B. Carroll defined degree of learning as time spent actually in learning divided by the time needed for learning. In order to propose a testable, quantifiable model of school learning, he gave some qualitative factors a time metric. In numerator of the fraction, opportunity and perseverance were defined as "time allocated for learning", and "the amount of time the learner is willing to engage actively in learning" respectively. In denominator, he proposed three factors of "aptitude", "quality of instruction", and "ability to understand instruction" among which aptitude was defined qualitatively as" the amount of time an individual needs to learn a given task under optimal instructional conditions". Through his model Carroll laid the groundwork for a new field of educational research in which researchers embarked on investigating the correlation between time spent on learning and achievement.

The ground work laid by Carroll's model made educationalists scrutinize the time factor in details for its different dimensions. The upshot was classification of different educational times. Nowadays, educational times can be conceived as an inverted pyramid: Allocated time on the upper tier, time-on-task or engaged time in the middle tier, and academic learning time at the bottom (Aronson, Zimmerman, \& Carlos, 1999). Allocated time is the amount of time assigned for instruction in a content area, without reference to the quality of the activities being conducted during that time. Engaged time, or time-on-task, refers to portions of time during which students are paying attention to a learning task and attempting to learn and excludes time spent socializing, daydreaming, engaging in antisocial behavior (Cotton, 1989). Academic learning time (ALT) is that part of allocated time during which a student is engaged with materials and activities in which a high level of success is attained, and in which the materials and activities are related to outcomes that are valued (Berliner,
1990).

New classification of educational time factors aroused the interest of some educationalists to work on the relation between these temporal variables and learners' level of achievement. A few studies (e.g., Wiley \& Harnischfeger, 1974) have found a strong positive relationship between allocated time and achievement, while some investigators have found virtually no relationship (e.g., Anderson, 1981; Borg, 1980; Brown \& Saks, 1986; Karweit, 1985).This relationship between engaged time and achievement has been proven to be stronger than that of allocated time and achievement but the finding should be interpreted with caution because the relationship is modest (Cotton, 1989; Quartarola, 1984; Seifert \& Beck, 1984; Cotton \& Savard 1981; Sanford \& Evertson 1983).The strongest relationship has been found between academic learning time and achievement. All researchers and reviewers who investigated its effects found it to bear a very close relationship to the achievement (e.g., Anderson, 1981; Borg, 1980; Cotton \& Savard, 1981; Fisher \& Berliner, 1985; Karweit, 1984; Mazzarella, 1984; \& Walberg, 1988).

As the above findings noted, the relationship between engaged time and achievement is inconsistent, significant in some studies but not so in others. Some educationalists attribute this to the quality of engaged time (Cotton, 1989) and some other factors which turn engaged time to academic learning time. In his famous model Slavin (1994) proposes four alterable elements of effective instruction quality, appropriateness, incentive, and allocated timewhich should be provided to expect to make a substantial difference in student achievement. In his model, engaged time comes between these factors and final step of achievement. The model has one important characteristic: All four elements must be adequate for instruction to be effective. Moreover, the four elements are multiplicatively related, in that improvements in multiple elements may produce substantially larger learning gains than improvements in any one. Therefore, instructional time factors like time-on-task or seatwork time can result in better achievement if substantial increases in any one element can be provided. Therefore, he attributes inconsistent relationship between engaged time and achievement to the presence or absence of the determinant factors.

"Academic learning time"(ALT) model is another model which accounts for the inconsistent results of engaged time and achievement, In this model four variables of "allocated time", "engaged time", "success rate", and " curriculum alignment with the outcome measure" take account of academic achievement( Berliner, 1990). The use of success rate in this model is an attempt to provide a time metric for the two non-time variables of "quality of instruction" and "ability to understand instruction". Moreover, "curriculum alignment with outcome" recognizes the time-on-the-righttasks which emphasizes on the appropriate content. The rationale is that it is very hard to demonstrate learning if the curriculum and the outcome measures used to assess 
learning are not aligned (Schwillie, et al., 1983).

Peculiar status of engaged time in the literature has paved the way for further specifications and creation of new terminologies to refer to subtypes of engaged time or time-on-task. One of the new areas of research in the domain of engaged time is "seatwork time". Seatwork means "reading, writing, or other work on lessons, done in school by students at their desks"(Webster's New World College Dictionary, 2005) and the amount of time given for seatwork activities is called "seatwork time".

Seatwork time and engaged time are not necessarily synonymous although they can overlap with each other. Engaged time doesn't exclude lecture-based instruction although for many educationalists, this mode of instruction is mostly translated into learners' passiveness (Mosca \& Howard, 1997; Bonwell, 1998; Papert, 2000). Seatwork time, on the contrary, includes the proportion of time when the teacher puts lecturing aside and provides students with opportunity for guided or independent practice. But these two times aim at the same target of mental engagement which in turn is a prerequisite for better achievement.

The notion of seatwork time for a researcher can be defined as the quantitative version of engaged time which is also qualitative in nature. Therefore, if a researcher asks a teacher to increase seatwork time in his class, he intends to increase participants' share of class time with the intention of increasing the rate of their mental engagement but nothing specific is preplanned to assure the occurrence of mental engagement. It doesn't mean that the teacher ignores the prerequisites of seatwork activities such as scaffolding, supervising, or giving feedback. The meager research findings support this notion that unmonitored seatwork and seatwork activities which are not matched to student ability levels are at best unrelated to achievement and sometimes have negative achievement effects (Quartarola 1984). When the given researcher is not content at this stage and wants to assess the rate of mental engagement by the available instruments, he has crossed the boarder of seatwork time and entered the realm of engaged time.

The literature on seatwork time-as the alternative to whole class instruction- is next to nothing as far as the author knows although plethora of research studies are available for comparing lecture-based instruction with its counterparts like independent learning, learner-centered teaching, self-directed learning, or discovery learning. The scarcity of literature on seatwork time effect on other variables like achievement can be attributed to the quantitative nature of seatwork time. Rosenshine (1979) believes that qualitative, not quantitative, factors are important for the effectiveness of independent practice in seatwork time. Adequate external conditions, minimum level of competency, and adequate level of monitoring and scaffolding have been proposed as some of these influential factors (Strother, 1984; Helmke \& Schrader, 1988).

Manipulation of seatwork time is less demanding than engaged time in which the researcher or teacher should observe learners and use checklists or rating scales to distinguish engaged behaviors from unengaged ones as the criteria for mental engagement. Regardless of validity and reliability of the instruments used, the application of results to a larger population entails the same complicated quality control procedure for optimal level of engagement as only one of the prerequisites for achievement. Seatwork time which is evaluated quantitatively, however, is manipulated easily with no double burden on teacher as facilitator and engagement rater in natural setting of the classroom in which presence of recording surveillance or observer interferes with the learners' concentration.

Evaluating an innovative view on educational time factors is the premise behind this study. In other words, this study aims at investigating the extent to which increasing seatwork time as a theoretically sound pedagogical innovation has a positive or negative effect on learners' academic achievement. Therefore, seatwork time as an educational time factor was manipulated in a quasiexperimental design to answer the following research question:

Does increasing seatwork time have significant effect on learners' achievement in English classes?

\section{Methodology}

\subsection{Participants}

Two high school first-grade classes were selected randomly from ten classes in one high school in Markazi province. The high school had registered 283 male first graders and had distributed them randomly among ten classes. The two randomly selected classes had 56 freshmen at the beginning of academic year. Six participants were excluded from the research because they left school during the year or didn't take part in pre-test or post-test sessions. Therefore, the participants were 5o first graders in two intact classes.

\subsection{Instrument}

Two teacher-made achievement tests were the instruments in the study. They were designed according to test specifications issued by ministry of education. After they were designed, four teachers evaluated the content validity of both tests. Their comments were incorporated and resulted in some modifications in these two tests. The first test, the pre-test, was designed based on the first half of the high school English book 1 (lesson 1, 2, 3, and 4) while the second test, post-test, evaluated the learners' performance on the second half of the book (lesson 5, 6, 7, 8, and 9). Both tests were assessed for test-retest reliability in a pilot study using Pearson product-moment correlation coefficient.

\subsection{Procedure}

At the beginning of the academic year from ten available classes two intact classes were selected randomly as control 
group and experimental group. Another class from the remaining classes was also selected to be used for assessing the reliability of the instruments in the pilot study. During the first semester, the first half of the text book was taught to all three classes similarly with allotting about thirty minutes $\left(1 / 3^{\text {rd }}\right.$ of allocated time $)$ to seatwork time in each ninety-minute session. The pre-test was administered to the third group twice with the interval of two weeks. After its reliability was assured $\left(\mathrm{r}_{\chi \chi}=.79\right.$ for pre-test; $\mathrm{r}_{\chi \chi}=.81$ for post-test), the sample took the test simultaneously and under the same circumstances. For the second part of the book, the control group was given the same amount of time to seatwork activities, thirty minutes as before, while the experimental group had sixty minutes $\left(2 / 3^{\text {rd }}\right.$ of allocated time) of each session for seatwork activities. Accuracy of time allocation to seatwork activities and whole class instruction was measured and registered by the teacher every other session. At the end of the semester the same procedure was run for the post-test to identify the subjects' achievement.

Both tests were scored and data were fed into to SPSS (Version 17). Because the mean scores in pre-test for both groups were not equivalent, ANCOVA was used to determine whether the means of two groups in post-test were significantly different if the initial difference in pretest was removed statistically.

\section{Results}

In order to answer research question, the data from two achievement tests were gathered and then submitted to statistical analyses. Descriptive data in Table (1) show the mean scores of both control and experimental groups in pre-test and post- test.

Table 1. Descriptive statistics

\begin{tabular}{|c|c|c|c|c|c|c|c|}
\hline & $\mathbf{N}$ & Mean & SD & Skewness & & Kurtosis & \\
\hline & Statistic & Statistic & Statistic & Statistic & Std. Error & Statistic & Std. Error \\
\hline Pre-test con. & 25 & 16.11 & 3.426 & .890 & .464 & .767 & .902 \\
\hline Post-test con. & 25 & 13.49 & 4.530 & .523 & .464 & -.430 & .902 \\
\hline Pre-test expe. & 25 & 16.26 & 4.027 & .404 & .464 & -1.287 & .902 \\
\hline Post-test expe. & 25 & 14.96 & 4.233 & .882 & .464 & -.239 & .902 \\
\hline Valid N (listwise) & 25 & & & & & & \\
\hline
\end{tabular}

As table (1) shows, experimental group outperformed in both pre-test and post-test. Initial difference between the groups in the pre-test entailed running analysis of covariance (ANCOVA). But before plugging data into ANCOVA, some assumptions were evaluated. The first assumption to be assured was independence of covariate and treatment effect which means that the covariate (pretest) should not be different between the groups. To test the assumption, an independent t-test was run. As the table (2) shows, Leven's test for equality of variances indicates that the variances are homogenous, ( $f=2.87, \mathrm{p}<0.05)$. Therefore, the results of t-test for equal variances were considered. The results of t-test supported the nonsignificant difference between the means of pre-test for the two groups, $\mathrm{t}(48)=-0.14, \mathrm{p}=.05)$ which, in turn, showed that the assumption of independence of covariate and treatment effect was not violated.

Table 2. independent samples t-test

\begin{tabular}{llllllll}
\hline & & \multicolumn{2}{c}{ Levene's Test for Equality of } & \multicolumn{2}{c}{ t-test for Equality of Means } \\
& & F & Sig. & t & df & Sig. (2-tailed) \\
\hline \multirow{2}{*}{ Pre-test } & Equal variances & 2.871 & .097 & -.147 & 48 & .884 & \\
& Unequal variances & & & -.147 & 46.798 & .884 & \\
\hline
\end{tabular}

Assumption of homogeneity of regression slopes was another consideration before running ANCOVA. As the results of table (3) show, the assumption was not violated because the interaction effect was not significant, $\mathrm{f}(1,46)$ $=0.66, \mathrm{p}<0.05)$.

Table 3. test of homogenity of regression slope

\begin{tabular}{lllll}
\hline Source & Tvpe III Sum of Squares & df & Mean Sauare & F \\
\hline Corrected Model & $615.639^{\mathrm{a}}$ & 3 & 205.213 & Sig. \\
Intercept & 2.880 & 1 & 2.880 & .000 \\
group * pre & 25.670 & 1 & 25.265 & .397 \\
Error & 333.978 & 46 & 7.260 & 3.536 \\
Total & 11073.978 & 50 & & .066 \\
Corrected Total & 949.617 & 49 & & \\
\hline
\end{tabular}


Homogeneity of variances for the post-tests was another tested assumption of ANCOVA. Levene's test of equality of variances also indicated that the variances of scores obtained from post-test in two groups were homogeneous, $\mathrm{f}$ $(1,48)=0.08, \mathrm{p}<0.05)$.

Table 4. Levene's test of equality of variances

\begin{tabular}{cccc}
\hline F & df1 & df2 & Sig. \\
\hline .088 & 1 & 48 & .767 \\
\hline
\end{tabular}

Normality assumption was the last assumption which was checked before running ANCOVA. There is no consensus among statisticians for a standard procedure for checking the normality assumption for parametric tests. Calculating skewness and kurtosis, examining histograms or plots, and Kolmogorov-Smirnov Z test of normality are three possible procedures for checking normality. Data on skewness and kurtosis in table (1) showed that only pre-test scores for experimental group are not normally distributed satisfactorily ${ }^{1}$. Statistical test of normality, however, did not support the violation of normality assumption for this set of data although it did prove the least amount of normality for it among others. As table (5) shows, all p-values are bigger than 0.05 which means that all data sets are normally distributed. Graphical examination of plots was in support of normality of data sets.

Table 5. test of normality

\begin{tabular}{|c|c|c|c|c|}
\hline & $\begin{array}{l}\text { Con. Pre- } \\
\text { test }\end{array}$ & $\begin{array}{l}\text { Con. Post- } \\
\text { test }\end{array}$ & $\begin{array}{l}\text { Exp. Pre- } \\
\text { test }\end{array}$ & $\begin{array}{l}\text { Exp. Post- } \\
\text { test }\end{array}$ \\
\hline $\mathrm{N}$ & 25 & 25 & 25 & 25 \\
\hline $\begin{array}{c}\text { Kolmogorov-Smirnov } \\
\mathrm{Z}\end{array}$ & .675 & .850 & 1.070 & .894 \\
\hline Asymp. Sig. (2-tailed) & .752 & .465 & .202 & .401 \\
\hline
\end{tabular}

After ANCOVA assumptions were assured, the main ANCOVA test was run. The results obtained from the ANCOVA run on the data ( presented in table 6) showed that, there was no significant difference between experimental group and control group in their post-test scores, $\mathrm{f}(1,47)=2.85, \mathrm{p}<0.05$. Therefore, the null hypothesis which stated that increasing seatwork time does not have any significant effect on the learners' achievement in English classes is supported.

\footnotetext{
${ }^{1}$. Skewness larger that $+/-1$ or so indicates that the data are not distributed normally
}

Table 6. ANCOVA test

\begin{tabular}{cccccc}
\hline Source & $\begin{array}{c}\text { Type III Sum of } \\
\text { Squares }\end{array}$ & df & $\begin{array}{c}\text { Mean } \\
\text { Square }\end{array}$ & F & Sig. \\
\hline $\begin{array}{c}\text { Corrected } \\
\text { Model }\end{array}$ & $589.969^{\mathrm{a}}$ & 2 & 294.985 & 38.550 & .000 \\
Intercept & .881 & 1 & .881 & .115 & .736 \\
Pre-test & 563.134 & 1 & 563.134 & 73.592 & .000 \\
Group & 21.870 & 1 & 21.870 & 2.858 & .098 \\
Error & 359.648 & 47 & 7.652 & & \\
Total & 11073.978 & 50 & & & \\
\hline $\begin{array}{c}\text { Corrected } \\
\text { Total }\end{array}$ & 949.617 & 49 & & & \\
\hline
\end{tabular}

a. $\mathrm{R}$ Squared $=.621$ (Adjusted R Squared $=.605$ )

b. Computed using alpha $=.05$

\section{Discussion}

The underlying rationale of this study was quantitative exploration of the effect of increasing seatwork time as an instructional time factor on the achievement of high school freshmen in high school English language classes. In a quasi-experimental design, two intact classes were given two different amounts of seatwork time and their performances were assessed before and after experimentation. The results showed that experimental group which experienced more seatwork time outperformed the control group which had relatively less seatwork time but the difference was not proven to be statistically significant. Therefore, it can be concluded that increasing the seatwork time does not result in better achievement in behalf of the learners.

The findings of the study are in line with the results of Helmke and Schrader's (1988) study which investigated the achievement effects of time spent on seatwork activities. The findings of this study showed that amount of seatwork per se have no effect on achievement. They found that the seatwork of higher-achievers was characterized by careful preparation, efficient management, active supervision, and discreet support and feedback on the part of their teachers. McGarity and Butts's (1984) study which examined relationships of various teacher behaviors to time-on-task also supported this notion that achievement is more related to close monitoring, providing feedback, maintaining learner, using instructional time effectively, and managing disruptive behavior rather than increasing the quantity of time-on-task. There are some other experimental studies focusing on increasing time on-task that have found that it is possible to increase engaged time and still have no significant effect on student achievement (see, for example, Emmer \& Aussiker, 1990; Slavin, 1987; Stallings \& Krasavage, 1986).

The results of the study are also consistent with Slavin's 
(1987) model of effective instruction which can be defined in terms of intermediate effects on time-related variables. His QAIT model considers "quality of instruction", "appropriate levels of instruction", "incentive", and "time" as four critical elements in instructional efficiency. $\mathrm{He}$ believes that all four must be adequately provided for an effective instruction. In a same vein, findings of this study are also supported by "academic learning time"(ALT) model. As stated before, in this model in addition to instructional time factors, "success rate" and "the curriculum alignment with outcome" pay their role in learning achievement. What was done in this study was a mere modification in or manipulation of one instructional time factor -seatwork time- and other determining factors were left untouched unless the new circumstance in experimental group rendered other factors changed.

The findings in the study showed that mere increase of seatwork time does not result in significantly better achievement in English classes. Those participants who enjoyed more seatwork time performed neither better nor worse than those who enjoyed less. The observed nonsignificant difference between the two groups can be interpreted in two ways: Firstly, the proportion of seatwork time to whole-class instruction time is the right balance obtained by teachers during many years of experience. Therefore, students are receiving the right amount of support during the whole-class instruction. Second, it can be inferred that the contributing factors to achievement proposed in Slavin's and ALT models are not adequately provided in context of the present study. Consequently, the findings of the study can be used as an indicator of deficiency in other instructional elements.

Regardless of this fact that which of these two inferences sounds valid, teachers are recommended to reconceptualize their role as a presenter. The experimental group in which the teacher allocated less time to whole-class instruction did perform neither better nor worse than the control group. Therefore, it can be concluded that even decreasing wholeclass instruction does not have any significant negative effect on learners' achievement. In line with the second inference, it is recommended that teachers see instructional time factors in an integrated system in which time factors and other factors interact with each other. In other words, manipulation of time factors should be viewed in the light of other factors. In fact, no single time factor leads to improvement or failure if other influential elements are ignored.

In order to get rid of hedges in inferences or recommendations of this study, new research studies should be conducted to hold other elements constant across groups to single out the effect of increasing seatwork time on achievement. For example, increasing seatwork time, like time-on-task, can be more beneficial with higher achievers than lower achievers. The amount of support and feedback learners receive is also very important. In this study participants received support whenever they demanded, but it was not included as a variable. A research study can be set up to investigate the effect of feedback as a moderator variable on the relationship between seatwork time and achievement.

\section{Conclusion}

Like many research studies which show no significant effect of increasing time-on-task on learners' achievement, the present study indicated that increasing seatwork time also doesn't have such an effect. This can be attributed to the appropriate balance between whole-class instructional time and seatwork time in traditional classes run dominantly by teachers' lecture. It can also be attributed to lack of indispensable elements like quality of instruction or motivation in educational settings. The former reason is not advocated by educational theorists because they urge teachers to put lecture-based instruction aside while the latter is more appealing to them as they view achievement as the upshot of interaction among so many factors one of which is time factor.

\section{References}

[1] Anderson, L. (1981). Instruction and time-on-task: A review. Journal of Curriculum Studies 13, 289-303.

[2] Aronson, J., Zimmerman, J., \& Carlos, L. (1999). Improving student achievement by extending school: Is it just a matter of time? Retrieved on June 19, 2006, from WestEd: http://www.wested.org/online_pubs/timeandlearning/TAL_P V.html

[3] Berliner, D. (1990). What's all the fuss about instructional time? The nature of time in schools theoretical concepts, practitioner perceptions. New York: Teachers College Press.

[4] Bonwell, C. C. (1998). Active learning: Energizing the classroom. Green Mountain Falls, CO: Active Learning Workshops.

[5] Borg, W. R. (1980). Time and school learning. In Time to Learn, edited by C. Denham and A. Lieberman. Washington, DC: National Institute of Education.

[6] Brown, B. W., \& Saks, D. H. (1986). Measuring the effects of instructional time on student learning: Evidence from the beginning teacher evaluation study. American Journal of Education 94, 480-500.

[7] Carroll, J. B. (1963) . A model of school learning. Teachers College Record, 64, 723-733.

[8] Cotton, K. (1989 ).Educational time factors .Portland, Ore.: Northwest Regional Education Laboratory.

[9] Cotton, K., \& Savard, W.G. (1981). Time factors in learning. Portland, OR: Northwest Regional Educational Laboratory.

[10] Dewey, J. (1916). Democracy and education. New York: Free Press.

[11] Emmer, E. T., \& A. Aussiker. (1990). "School and classroom discipline programs: How well do they work?" Students discipline strategies. Ed. O. C. Moles. Albany: State University of New York Press. 
[12] Fisher, C. W., \& Berliner, D. C. (Eds.). (1985). Perspectives on instructional time. New York: Longman.

[13] Helmke, A., \& Schrader, F.W.(1988). Successful Student Practice during seatwork: Efficient management and active supervision not enough. Journal of Educational Research, $82,70-75$.

[14] Karweit, N. (1985). Should we lengthen the school term? Educational Researcher, 14, 9-15.

[15] Mazzarella, J.A. (1984). Longer day, longer year: Will they make a difference?" Principal. 63, 14-20.

[16] McGarity, J. R. \& Butts, D. P. The relationship among teacher classroom management behavior, student engagement, and student achievement of middle and high school science students of varying aptitude. Journal of Research in Science Teaching. 21. 55-61.

[17] Moore, M. G. and Kearsley, G. (1996) Distance education: A systems view. Belmont, CA: Wadsworth.

[18] Mosca, J. \& Howard, L. (1997). Grounded learning: Breathing live into business education. Journal of Education for Business. 73, 90-93.

[19] Papert, S. (2000). What's the big idea?: Toward a pedagogy of idea power. IBM Systems Journal. 39(3/4), 720-729.

[20] Quartarola, B.( 1984). A research paper on time on task and the extended school day/year and their relationship to improving student achievement. Sacramento, CA: Research, Evaluation, and Accreditation Committee, Association of California School Administrators.

[21] Rosenshine, B.V. (1979). Content, time, and direct instruction." In Resreach on teaching: Concepts, finding, and implications. edited by P.L. Peterson and H.J. Walberg. Berkeley, CA: McCutchan Publishing Corp.

[22] Sanford, J. P., \& Evertson, C. M. (1983). Time use and activities in junior high classes. Journal of Educational Research. 76, 140-147.
[23] Schwillie, J., Porter, A., Belli, G., Floden, R., Freeman, D., Knappen, L., Kuhs, T., \& Schmidt, W. (1983). Teachers as policy brokers in the control of elementary school mathematics. In L. S. Shulman \& G. Sykes (Eds.), Handbook of teaching and policy (pp. 320-91). New York and London: Longman.

[24] Seatwork. (2009). In Webster's New World College Dictionary Retrieved August 6th, 2009, from www.yourdictionary.com/seatwork)

[25] Seifert, E. H., \& Beck, J, (1984). Relationships between task time and learning gains in secondary schools. Journal of Educational Research 78, 5-10.

[26] Slavin, R.E. (1987). Mastery learning reconsidered. Review of Educational Research, 57,175-213.

[27] Soo, K. S., \& Bonk, C. J. (1998). Interaction: What does it mean in online distance education? Paper presented at the Ed-Media and EdTelecom 98 conference, Freibourg, Germany.

[28] Stallings, J., \& Krasavage, E. M. (1986). Program implementation and student achievement in a four-year madeline hunter follow through project." Elementary School Journal 87, 117- 138.

[29] Strother, D. B.(1984). Another look at time on task. Phi Delta Kappan 65, 714-717.

[30] Tuovinen, J. E. (2000). Multimedia distance education interactions. Educational Media International, 37(1), 16-24.

[31] Walberg, H. (1988). Synthesis of research on time and learning. Educational Leadership, 45(6), 76-85.

[32] Wiley, D. \& Harnishfeger, A. (1974). Explosion of a myth: quantity of schooling and exposure to instruction, major educational vehicles. Educational Researcher, 3(4),7-12.

[33] Williams, M., \& Burden, R. L. (1997). Psychology for language teachers: A social constructivist approach. Cambridge: Cambridge University Press. 